\title{
Relationships between various attitudes towards self-determination in health care with special reference to an advance directive
}

Martin Eisemann and Jörg Richter Umeå University, Umeå, Sweden and Rostock University, Rostock, Germany respectively

\begin{abstract}
Objectives-The subject of patient

self-determination in health care has gained broad

interest because of the increasing number of

incompetent patients. In an attempt to solve the problems related to doctors' decision making in such circumstances, advance directives have been developed. The purpose of this study was to examine relationships between public attitudes towards patient autonomy and advance directives.

Subjects and main outcome measures- $A$ stratified random sample of 600 adults in northern Sweden was surveyed by a questionnaire with a response rate of $78.2 \%$. The subjects were asked about their wish for control of their health care, their concerns about health care, their treatment preferences in a life-threatening situation (both reversible and irreversible), and their attitudes towards the application of advance directives. Results-Numerous relationships between various aspects of self-determination in health care (desire for control, fears of over-treatment, and choice of treatment level) in general and advance directives, in particular, were found. Those who wanted to have a say in their health care (about 94\%) also mainly supported the use of an advance directive.

Conclusions-The fact that almost $30 \%$ of the respondents were undecided concerning their personal use of advance directives points to a lack of knowledge and to the necessity of education of the public on these issues.
\end{abstract}

(Fournal of Medical Ethics 1999;25:37-41)

Keywords: Self-determination in health care; general population survey; advance directive; patient education

\section{Objectives}

In industrialised Western countries the proportion of elderly people among the total population is constantly increasing. Simultaneously, the number of elderly among the patients in the health care system is growing. One of the concurrent problems of this development which health care professionals are encountering is the increasing proportion of incompetent patients, for example those who are not able to communicate their treatment preferences. ${ }^{1-3}$ Another group, who present similar problems, and who are also increasing in numbers, are patients suffering from AIDS.

Today, more than ever before, elderly people express fears of an overzealous use of lifesustaining procedures when they are severely ill; procedures which would just prolong their suffering and compromise their dignity and quality of life. ${ }^{45}$ These concerns have been manifested both in general population ${ }^{6-9}$ and patient surveys. ${ }^{1011}$ These investigations revealed the public's considerable and widespread interest in selfdetermination in health care.

One way of promoting patients' selfdetermination is by the use of so-called advance directives, which allow individuals to express and document their treatment preferences at a time when they are competent, and to inform others (i e health care professionals) how they would like to be treated in case of incompetency. ${ }^{4912}{ }^{13}$ Such documents could reduce conflicts in the doctor's decision-making process. ${ }^{6}{ }^{14}$ Results from the above-mentioned population surveys clearly indicate the willingness of the public to use advance directives. A survey of 405 outpatients at the Massachusetts General Hospital in Boston, USA revealed that $93 \%$ desired an advance directive ${ }^{4}$; similar results $(92.3 \%)$ were obtained from a $909-$ subjects sample in Canada by Molloy and co-workers.' Among our representative general population sample in northern Sweden almost $80 \%$ regarded it as extremely or very important to document in an advance directive the level of care they would like to get in the event of an acute lifethreatening illness. ${ }^{6}$ 
38 Relationships between various attitudes towards self-determination in health care with special reference to advance directive

Table 1 Characteristics of the sample (age categories by sex $-n / \%$ )

\begin{tabular}{|c|c|c|c|c|c|c|c|c|}
\hline years & $20-29$ & $30-39$ & $40-49$ & $50-59$ & $60-69$ & $70-79$ & $80-89$ & total \\
\hline females & $36 / 52.2$ & $35 / 48.6$ & $30 / 46.2$ & $51 / 54.3$ & $39 / 48.1$ & $38 / 48.1$ & $6 / 50.0$ & $235 / 49.8$ \\
\hline males & $33 / 47.8$ & $37 / 51.4$ & $35 / 53.8$ & $43 / 45.7$ & $42 / 51.9$ & $41 / 51.9$ & $6 / 50.0$ & $237 / 50.2$ \\
\hline total & $69 / 14.6$ & $72 / 15.3$ & $65 / 13.8$ & $94 / 19.9$ & $81 / 17.2$ & $79 / 16.7$ & $12 / 2.5$ & 472 \\
\hline
\end{tabular}

These unequivocal results urge both health policy makers and health care professionals to prepare the way for increased patient self-determination and for the implementation of advance directives.

The aim of the present study was to analyze the relationships between various attitudes towards self-determination concerning medical treatment in general and towards advance directives, in particular. These might constitute a basis for identifying crucial points for the education of the public in these issues.

\section{Subjects}

GENERAL POPULATION SURVEY

A stratified random sample of 600 adults, 20 years of age or older was obtained from the registration office of the province of Västerbotten in northern Sweden. The subjects were representative according to age-decades and gender. During May 1996 they were mailed a questionnaire and a covering letter, in which the voluntariness of participation was emphasised. Those who did not return the questionnaire received a first reminder after three weeks. After another four weeks a second reminder was sent to the non-responders. Altogether 472 subjects returned the questionnaire, a response rate of $78.2 \%$.

The project had previously been approved by the ethical committee at Umeå University.

\section{Measurement}

\section{QUESTIONNAIRE}

The questionnaire, originally developed by Molloy and co-workers from the Geriatric Research Group at McMaster University, Canada, ${ }^{9}$ was translated into Swedish according to established guidelines including appropriate use of independent back translations. In the first part of the questionnaire biographical data were ascertained (age, sex, civil status, occupational status, chronic disease). Subsequently, the subjects were asked about: a) their wish for control of their personal health care, b) attitudes towards current health care practice, $c$ ) their preferences for treatment in a life-threatening situation, both where it was reversible and where it was irreversible, and d) their attitudes towards the application of advance directives. An example of an advance directive form was presented at the end of the questionnaire. $^{15}$
The respondents were asked to reply either on five-point scale: extremely, very, somewha slightly, not important/concerned, or on a thre $\bar{E}$ point scale: yes, no, undecided, respectively. concerns treatment preferences in case of reversible or irreversible, acute life-threatenirig condition, four options were given: a) comfort measures only - pain relief, intravenous medic tions, no tests, b) limited efforts - pain relied, intravenous medications, tests, but no surgery, moderately aggressive treatment - no intensive care unit, no ventilator, but surgery, if indicate $\$$ and $d$ ) very aggressive treatment - intensive caris unit and ventilator, if necessary.

The statistical analysis was performed by means of frequency tables and $\chi$-square tests. $\mathrm{X}$-square $\$$ a test of statistical significance which is done ip order to determine whether a systematic relatior ship exists between two variables.

\section{Results}

SAMPLE CHARACTERISTICS

The mean age of the subjects was $51.3 \pm 17.8$ years and they were equally distributed within seven ag decades, except the group of 50 to 59 years od and the group of 80 to 89 years old (table 1). The sexes were represented by $50 \%$ each. Further details are given elsewhere. ${ }^{6}$

IMPORTANCE OF CONTROL

The questionnaire comprised two question regarding control of their own health care, one a general nature and a second focusing on advance्c. directives (level of care in the event of an acute life-threatening illness). The results showed thag desire for control was significantly related to thie following aspects: a) concerns about beine subjected to tests and procedures without prio discussion and consent $\left(\chi^{2}=36.35 ; 65.02 ; \mathrm{p}\right.$ 言 0.003 ; p < 0.001); b) concerns about not bein treated aggressively enough at hospital $\left(\chi^{2} \geqslant\right.$ $26.83 ; 46.95 ; \mathrm{p}=0.043 ; \mathrm{p}<0.001)$; c) wish to discuss treatment options with the doctor $\left(\chi^{2}\right.$ 皇 57.01; 29.49; $\mathrm{p}<0.001 ; \mathrm{p}=0.003)$;) wish document desired level of care in the event of a acute life-threatening condition $\left(\chi^{2}=61.4\right.$ 多 96.83; $\mathrm{p}<0.001 ; \mathrm{p}<0.001)$; e) regarding the presented directive in the questionnaire as usefig. $\left(\chi^{2}=18.92 ; 42.05 ; \mathrm{p}=0.015 ; \mathrm{p}<0.001\right)$; $)$ wish to use the presented directive $\left(\chi^{2}=14.34 ; 55.6 \mathrm{i}\right.$; 
Table 2 Evaluation of the usefulness of presented directive and the wishes for using it (in \%)

\begin{tabular}{|c|c|c|c|}
\hline Question & yes & no & don't know \\
\hline Do you think this directive is useful? & 49.5 & 5.9 & 44.5 \\
\hline $\begin{array}{l}\text { Would you use this directive for directing the level of care provided to you in the event of } \\
\text { reversible/irreversible life-threatening illness? }\end{array}$ & 59.2 & 11.6 & 29.2 \\
\hline
\end{tabular}

$\mathrm{p}=0.073 ; \mathrm{p}<0.001$ ), and $\mathrm{g}$ ) the opinion of the respondents, as to which group of individuals the presented directive should be used by $\chi^{2}=33.54$; $50.31 ; \mathrm{p}=0.029 ; \mathrm{p}<0.001)$. With all of these associations the more important the subjects felt control over their own health care to be, the more pronounced were their wishes regarding selfdetermination, and the more frequently they expressed the opinion that such a directive should be used by everybody.

Furthermore, the perceived importance of desire for control by an advance directive was alone related with concerns about being treated too aggressively $\left(\chi^{2}=36.20 ; \mathrm{p}=0.003\right)$, indicating a specific association between fear of overzealous treatment and the importance of advance directives.

\section{CONCERNS}

All three sources of fear: of treatment and diagnosis without prior discussion and consent $-\chi^{2}=$ $22.15, p=0.005$; of treatment that was not aggressive enough $-\chi^{2}=27.65, p<0.001$; and/or of treatment in hospital that was too aggressive $-\chi^{2}$ $=17.62, p=0.024$, were related to the wish to document the desired level of care. In other words, the more fear the subjects expressed, the more they wanted to direct their level of care. Specifically, the subjects who were most concerned about overtreatment were the ones who tended to decide to use the presented directive $\left(\chi^{2}\right.$ $=14.51 ; \mathrm{p}=0.069$ ).

\section{TREATMENT LEVEL}

The expressed wish for participation in the decision-making process (wish to discuss hospital treatment and investigation issues with the doctor and wish to document desired level of care) were related to regarding the directive as useful $\left(\chi^{2}=\right.$ $19.23 ; \chi^{2}=82.56 ; \mathrm{p}=0.023 ; \mathrm{p}<0.001$, respectively) and to the willingness to use this directive $\left(\chi^{2}=24.49 ; \chi^{2}=92.29 ; \mathrm{p}<0.001 ; \mathrm{p}<\right.$ 0.001 , respectively).

Those subjects who favoured a documentation of their desired level of care also suggested to a larger extent than other subjects that everyone should use this kind of advance directive $\left(\chi^{2}=\right.$ 57.35; $p<0.001)$.

The selected treatment level in the event of both an acute reversible and an irreversible lifethreatening illness was associated with the per- ceived importance of having a say in one's own health care decisions $\left(\chi^{2}=39.06 ; \chi^{2}=36.05 ; p=\right.$ $0.001 ; p=0.003$, respectively) and with the perceived importance of having an advance directive under such circumstances $\left(\chi^{2}=25.52 ; \chi^{2}=\right.$ $32.91 ; \mathrm{p}=0.061 ; \mathrm{p}=0.008$, respectively).

\section{USE OF DIRECTIVE}

About $50 \%$ of the respondents thought the presented directive ${ }^{15}$ could be useful, only $5.9 \%$ evaluated the directive as not useful, but $44.5 \%$ were unable to decide (table 2). Nearly two-thirds of the subjects wanted to use this directive, $11.6 \%$ did not want to use it, (table 2) and about two-thirds indicated that everyone should use this directive (table 3). Most of the respondents expressed the opinion that this directive ought to be reviewed and updated every 12 months (table 4).

Those individuals who considered the presented directive as useful would like to use it for themselves $\left(\chi^{2}=279.14 ; p<0.001\right)$. Furthermore, both those who declared the directive to be useful and those who would use it advocated its general use $\left(\chi^{2}=125.15 ; \chi^{2}=164.77 ; p<0.001\right.$; $\mathrm{p}<0.001$, respectively) and the updating of an advance directive every 12 months $\left(\chi^{2}=28.04 ; \chi^{2}\right.$ $=32.49 ; \mathrm{p}<0.001 ; \mathrm{p}=0.002$, respectively).

On the other hand, those encountering difficulties in understanding this directive were less positive and more reluctant concerning its usefulness $\left(\chi^{2}=43.34 ; \mathrm{p}<0.001\right)$ and its personal use $\left(\chi^{2}=\right.$ $32.96 ; \mathrm{p}<0.001)$. Therefore, they were also more sceptical about a general dissemination of advance directives $\left(\chi^{2}=44.40 ; \mathrm{p}=0.001\right)$.

\section{CONFOUNDING VARIABLES}

When testing for confounding variables, for example, age, gender and presence of chronic ill-

Table 3 Who should use the presented directive? (in \%)

\begin{tabular}{lllllll}
\hline users & healthy & $\begin{array}{l}\text { chronically } \\
\text { ill }\end{array}$ & $\begin{array}{l}\text { acutely } \\
\text { ill }\end{array}$ & everyone & nobody & others \\
\hline $\mathrm{n}$ in $\%$ & 11.7 & 6.0 & 5.3 & 61.1 & 12.9 & 3.0 \\
\hline
\end{tabular}

Table 4 Expressed opinion about the frequency of updating the advance directive

\begin{tabular}{lllllll}
\hline months & 3 & 6 & 9 & 12 & not at all & others \\
\hline $\mathrm{n}$ in \% & 9.9 & 15.8 & 1.7 & 44.7 & 8.3 & 19.6 \\
\hline
\end{tabular}


ness, the following few relationships occurred. ${ }^{6}$ Age was inversely correlated to choice of treatment level as regards reversible illness $\left(\chi^{2}=40.38\right.$; $\mathrm{p}<0.010)$ and positively correlated to concerns about being treated too aggressively $\left(\chi^{2}=51.85 ; p\right.$ $<0.001)$. Regarding gender differences, females attached more importance to having control in health care decisions $\left(\chi^{2}=22.46 ; p<0.001\right)$ and expressed generally more concerns $\left(\chi^{2}\right.$ from 10.60 to $11.50 ; \mathrm{p}$ from 0.032 to 0.022 ) about their health care compared to their male counterparts.

\section{Conclusions}

The results confirm the correctness of our original assumption that it is necessary to study public attitudes towards self-determination in health care; and this is underscored by the high response rate obtained in our general population survey. ${ }^{6}$

Numerous relationships between various aspects of self-determination with regard to medical treatment in general and advance directives in particular could be established. We found desire for control highly related to fears concerning: treatment and diagnosis without prior discussion; undertreatment, and overtreatment. Consequently, the wish for self-determination was associated with support for advance directives. These relationships became most pronounced with regards to the fear of being too aggressively treated. Those who wanted to have a say in their health care (about 94\%) also predominantly expressed a wish to use the presented advance directive; only $11.6 \%$ of the subjects rejected it. The more important self-determination in health care was perceived to be, the more a lower level of treatment was selected. The great majority wish to use an advance directive to indicate their future choice of treatment level. Nevertheless, almost $30 \%$ of the respondents were undecided concerning their personal use of the presented directive. In addition, our findings of a relationship between difficulties among the respondents in understanding the directive and their rejection of it, and their general unfamiliarity with what an advance directive is, point to the necessity of educating the general public in the field of patient autonomy. ${ }^{16}{ }^{17}$

In ethics, autonomy implies acting with intention, with understanding and without controlling influences, ${ }^{18}$ all these characteristics underlining the individual desire for information. The finding of more concern about being treated too aggressively among the elderly age groups indicates a relation between older peoples' views on technology and the principle of beneficence in terms of ensuring their quality of life after treatment. Furthermore, the fear of overtreatment and possible prolonged suffering and pain during the dying process is related to the principle of non maleficence, ie, the ethical requirement to do no harm.

Considering these findings, the following issue should be addressed as part of the process of ed $\frac{T^{2}}{T^{2}}$ cating the general public:

a) clarification of the treatment possibilities कf modern medicine ${ }^{19}$;

b) information about doctors' responsibilitieg concerning medical treatment according law and medical ethics ${ }^{20}$;

c) information about doctors' ethical and lega conflicts in medical decision making and their acceptance and support of advances directives $^{2-20}$;

d) information about patients' rights and the legat basis of self-determination in health care ${ }^{21}$; and

e) information about advance directives, and education in completing such forms, coverin consideration of the available options and the implications of patients' decisions. ${ }^{4-15}$

In order to ensure the success of such large-scalg educational measures mechanisms have to bs found for their implementation. The family physi cian seems most suited to be the key person i⿱艹 this, which in turn requires that this group of health care professionals be prepared for th $\overrightarrow{\underline{6}}$ important and challenging task. ${ }^{416} 192223$

Promising steps have been taken in Canada boup Molloy and his Geriatric Research Group at McMaster University in Hamilton, who hav developed an advance health care directive and educational material which seem to be feasible practical and well supported both by various patient groups and by health care professionals. ${ }^{24-26}$

Martin Eisemann, PhD, is Associate Professor at the Unit of Medical Psychology, Department of Psychios try and WHO Collaborating Centre, Umea Univeño sity, Umeå/Sweden and förg Richter, PhD, 40 Associate Professor at the Psychiatric Universit Clinic, Rostock University, Rostock, Germany.

\section{References}

1 Arcangelo $\mathrm{V}$. Should age be a criterion for rationing health care? Nursing Forum 1994; 29: 25-9. 2 Kapp MB. 'Ageism' and right to die litigation. Medicine $\mathcal{E}$ La积

3 Nuckton TJ, List ND. Age as a factor in critical care un admissions. Archives of Internal Medicine 1995;155:1087-92.

4 Emanuel LL, Barry MJ, Emanuel EJ, Stoeckle JD. Advance directives for medical care - a case for greater use. New England Fournal of Medicine 1991;324:889-95.

5 Smedira NG, Evans BH, Grais LS. Withholding ane withdrawal of life support from the critically ill. New Englan Fournal of Medicine 1990;322:309-15.

6 Eisemann M, Eriksson M, Nordenstam M, Richter J, Mollo $\vec{y}^{+}$ DW. Attitudes towards self-determination in health care - a 
general population survey in northern Sweden. European fournal of Public Health 1998 (in press).

7 Elder NC, Schneider FD, Zweig SC, Peters jr PG, Ely JW. Community attitudes and knowledge about advance directives. fournal of the American Board of Family Practitioners 1992;5: 565-72.

8 Kuuppelomaki M. Ethical decision making on starting terminal care in different health-care units. Fournal of Advanced Nursing 1993;18:276-80.

9 Molloy DW, Guyatt GH, Alemayehu E. Treatment preferences, attitudes toward advance directives and concerns about health care. Humane Medicine 1991;7:285-90.

10 Edinger W, Smucker DR. Outpatients' attitudes regarding advance directives. Fournal of Family Practice 1992;35:650-3.

11 Sam $M$, Singer PA. Canadian outpatients and advance directives: poor knowledge and little experience but positive attitudes. Canadian Medical Association fournal 1993;148:14971502.

12 Broadwell AW, Boisaubin EV, Dunn JK, Engelhardt jr HT. Advance directives on hospital admission: a survey of patient attitudes. Southern Medical fournal 1993;86:165-8.

13 Emanuel LL, Emanuel EJ. The medical directive: a new comprehensive advance document. fournal of the American Medical Association 1989;262:3288-93.

14 Kelner M. Advance directives: the view of health care professionals. Canadian Medical Assocation fournal 1993;148: 1331-8.

15 Molloy DW, MephamV. Let me decide. Toronto: Penguin, 1992.

16 Duffield P, Podzamsky JE. The completion of advance directives in primary care. Fournal of Family Practice 1996;42: 378-84.
17 Molloy DW, Guyatt GH, Alemayehu E, McIlroy W, Willan A Eisemann $\mathbf{M}$, et al. Factors affecting physicians' decisions on caring for an incompetent elderly patient: an international study. Canadian Medical Association fournal 1991;145:947-52.

18 Beauchamp TL, Childress JF. Principles of biomedical ethics. New York: Oxford University Press, 1989.

19 Murphy C, Sweeney MA. Conflict resolution with the end of life decisions in critical care settings. Medinfo 1995:8: pt 2.

20 Thomasma DC. The ethical challenge of providing health care for the elderly. Cumberland Quarterly of Health Care Ethics 1995; 4:148-62.

21 Whithe BD, Singer PA, Siegler M. Continuing problems with patient self-determination. American fournal of Medical Quality 1993;8:187-93.

22 Davitt JK, Kaye LW. Supporting patient autonomy: decision making in home care. Social Worker 1996;41:41-50.

23 Mower WR, Baraff LJ. Advance directives. Effect of type of directive on physicians' therapeutic decisions. Archives of Internal Medicine 1993;153:375-81.

24 Darzins P, Molloy DW, Harrison C. Treatment for lifethreatening illness. New England fournal of Medicine 1993;329. 736.

25 Guyatt GH, Mitchell A, Molloy DW, Capretta R, Horsman J, Griffith $\mathrm{L}$. Measuring patient and relative satisfaction with level of aggressive care and involvement in care decisions in the context of life threatening illness. Fournal of Clinical Epidemiology 1995;48:1215-24

26 Molloy DW Guyatt GH. A comprehensive health care directive in a home for the aged. Canadian Medical Association fournal 1991;145:307-11.

\section{News and notes}

\section{Journal of Medical Ethics - http://www.jmedethics.com}

Visitors to the world wide web can now access the fournal of Medical Ethics either through the BMJ Publishing Group's home page (http:// www.bmjpg.com) or directly by using its individual URL (http://www.jmedethics.com). There they will find the following:

- Current contents list for the journal

- Contents lists of previous issues

- Members of the editorial board

- Subscribers' information

- Instructions for authors

- Details of reprint services.
A hotlink gives access to:

- BMJ Publishing Group home page

- British Medical Association website

- Online books catalogue

- BMJ Publishing Group books.

The web site is at a preliminary stage and there are plans to develop it into a more sophisticated site. Suggestions from visitors about features they would like to see are welcomed. They can be left via the opening page of the BMJ Publishing Group site or, alternatively, via the journal page, through "about this site".

\section{News and notes}

\section{Health Care Issues in Pluralistic Societies}

A seminar on Health Care Issues in Pluralistic Societies, organised by the International Programme in Bioethics Education and Research, will be held in Nijmegen, the Netherlands, 2 - 6 August, 1999.

Special attention will be paid to European traditions in health care ethics. All lectures and plenary sessions will be held in English.

Price: Dfl 950.
For more information please contact: B Gordijn, PhD, Catholic University of Nijmegen, 232 Dept of Ethics, Philosophy and History of Medicine, PO Box 9101, 6500 HB Nijmegen, the Netherlands. Tel: (31) 24-3615320; fax: (31) 24-3540254. E-mail: b.gordijn@efg.kun.nl / Internet site: http://www.azn.nl/ fmw/onderwys/ukbioeth.htm 